\title{
SPRY4-IT1 wt Allele
}

National Cancer Institute

\section{Source}

National Cancer Institute. SPRY4-IT1 wt Allele. NCI Thesaurus. Code C98180.

Human SPRY4-IT 1 wild-type allele is located in the vicinity of 5q31.3 and is approximately 700 bp in length. This allele, which encodes SPRY4 intronic transcript 1 (non-protein coding) RNA, may be involved in melanoma cell proliferation and survival. 